\title{
A novel approach to inoperable or recurrent rectal cancer by chemoembolization. A new arrow in our quiver?
}

\author{
Roberto Bini ${ }^{1}$, Simone Comelli ${ }^{2}$, Renzo Leli ${ }^{1}$, Giacomo Paolo Vaudano ${ }^{2}$, Daniele \\ Savio ${ }^{2}$, Tiziana Viora ${ }^{1}$, Alfredo Addeo $^{3}$ \\ ${ }^{1}$ General Surgery Department, SG Bosco Hospital, Turin, Italy \\ ${ }^{2}$ Interventional Radiology- Neuroradiology Department, SG Bosco Hospital, Turin, Italy \\ ${ }^{3}$ Oncology Department, Bristol Cancer Center, Bristol, UK \\ Correspondence to: Roberto Bini, email: rebinidoc@gmail.com \\ Keywords: debiri, rectal cancer, chemoembolization, cancer recurrence
}

Received: November 09, $2015 \quad$ Accepted: May 20, 2016

Published: June 10, 2016

\section{ABSTRACT}

Purpose: Assess the feasibility, safety and efficacy of TACE with irinotecan loaded micro particles (debiri) for the treatment of locally advanced rectal cancer patients.

Results: We assessed the Edmonton Symptom Assessment System (ESAS). The tool is designed to assess nine common symptoms in cancer patients: pain, tiredness, nausea, depression, anxiety, drowsiness, appetite, wellbeing and shortness of breath. The ESAS score was 7 in 10/12 (83\%) patients before treatment and 6 in 2/12 $(16.5 \%)$ patients. After treatment in $6 / 12(50 \%)$ patients the score dropped to 3 ; $3 / 12(33 \%)$ reported $4,1 / 12(8 \%)$ reported 2 . All patients experienced local control disease with a degree of citoreduction; in 4 cases (33\%) we observed outstanding responses with a dramatic reduction in the tumors size which led us to surgical radical resections.

Materials and methods: We run a prospective mono-institutional study where we recruited, 12 non- consecutive patients with histology confirmation of rectal cancer, inoperable and not treatable due to severe comorbidities, or pelvic recurrence/ progression after curative treatment, chemotherapy, radiotherapy and/or surgery. Their performance status (PS) ECOG was 2-3. Twelve patients (10 male and 2 female) with a median age 71 (range 56-89) were recruited in the study.

Conclusions: The study has met the primary endpoint and showed encouraging activity. Debiri could be a possible option for locally advanced/inoperable or recurred rectal cancer patients. Further trials are warranted to validate this methodic in early stages.

\section{INTRODUCTION}

Colorectal cancer (CRC) is a leading cause of death, accounting for nearly $10 \%$ of all cancer deaths in Western countries. The incidence of rectal cancer in the European Union is $\sim 35 \%$ of the total colorectal cancer incidence, i.e. $15-25 / 100000$ per year. [1]. The mortality is $4-10 / 100$ 000 per year. The overall survival of the patients who do not undergo surgery is rather poorwith less than $25 \%$ of the patients alive at 5-year [2]

About $10 \%-30 \%$ of the rectal cancer patients at diagnosis could only receive palliation and approximately $40 \%$ of patients, treated with curative intent, develop recurrence that, for the vast majority, cannot be treated with curative intent [3].

Pelvic recurrent rectal cancer remains a challenging clinical problem, and patients generally have a dismal prognosis and a poor quality of life. Goal of palliative care is relieving disease-related symptoms and improving the patient's quality of life [4]. Radical surgical resection of recurrent rectal cancer remains the gold standard; several neoadjuvant treatments have been taken into consideration to increase the resectability rate and to improve long-term survival.

Among them we have been developed an interest in the transarterial chemoembolization (TACE): a 
minimally invasive therapeutic procedure performed by interventional radiologists that delivers drug intraarterially in order to stop the vascular supply to the tumour itself and that could be combined with chemotherapy agents, such as Irinotecan $[5,6]$.

Despite TACE has been widely used in the treatment of liver lesions either secondary or primary, there isn't robust evidence to support such a procedure in the neoadjuvant setting or in locally advanced rectal cancer.

TACE has been performed for many years with a variety of different devices, one of them is the embolic drug-eluting bead (DEB) system where the drug carrier is delivered intra-arterially through catheters that can be positioned close to the main arterial supply that feed particular tumors, causing primarily a physical blockage of the artery in combination with a sustained local delivery of the drug.

We have run a mono institutional study of TACE combined with DEB containing irinotecan (DEBIRI) in locally advanced/inoperable rectal cancer. DEBIRI seems to reduce arterial inflow and drug washout and maximize contact time between the drugs and the tumor cells which results in greater tumour necrosis [7]. The chemotherapy agent, once eluted from the beads, has a very high local concentration which overcomes possible resistance mechanism. The tumour response is likely to be greater than the one with standard arterial infusion.

The primary end points of this study were the feasibility, safety and symptoms control of TACE-DEBIR as treatment of locally advanced rectal cancer patients unsuitable for any other treatment options; the secondary end points were response rate,(RR) which was defined as the volume reduction of target lesions and overall survival (OS).

Alongside the study we issued a quality of evaluation life (QoL) adopting Edmonton scale [8] and EORTC QLQ-C30 [9].

\section{RESULTS}

\section{Patients and treatment characteristics}

Twelve patients (10 males and 2 females) were treated with TACE-Debiri. Eleven had the procedure once and only 1 patient required the treatment twice. (Table 1). The median age was 71( range 56-90): 4 patients had unresectable rectal cancer, not eligible for radiotherapy (RT) or chemotherapy (CHT) due to severe comorbidities, 5 patients presented with isolated pelvic recurrence after surgical resection and conventional treatment including chemotherapy (CHT) and/or radiotherapy (RT) and 3 patients progressed straight after CHT/RT with a locally advanced rectal cancer. All patients presented at the time of the study with at least the one of the following symptoms: obstruction to faecal transit, bleeding and or severe pain. The patients' characteristics are listed in Table 1. Quality of life (QoL) was reported adopting Edmonton scale and EORTC QLQ-C30.

At the time of the procedure 4 out of 12 patients were naïve from any treatment but deemed unfit due to heavy comorbidities, whereas the remaining ones $(8 / 12)$ had progressed after surgery and/or chemotherapy and radiotherapy and not suitable for any further treatment. (One patient had only radiotherapy prior to Debiri).

\section{Efficacy}

To assess the impact on patients 'symptoms we adopted the Edmonton Symptom Assessment System (ESAS). This tool has been designed to assess several cancer's symptoms: pain, tiredness, nausea, depression, anxiety, drowsiness, appetite, wellbeing and shortness of breath with the use of an alfa numeric scale that goes from 0 , no symptom, to 10 , maximum intensity of that symptom.

Overall the ESAS score improved in all score points: the pain score was 7 in $10 / 12(83 \%)$ patients before treatment and 6 in 2/12 (16.5\%) patients. After treatment in $6 / 12(50 \%)$ patients the pain score dropped to 3 for $6 / 12$ (50\% of the patients), 5/12 (41\%) reported pain score of 4 and in $1 / 12$ case $(9 \%)$ the pain reported was 2 .

Using EORTC QLQ-C30, the overall mean score decreased from 3 to 2 in 12/12 patients (100\%).

All patients experienced local disease control; in $4 / 12$ cases $(33 \%)$ we observed an outstanding radiological response with a dramatic reduction in the tumor size which led us to radical surgical resection. (Figures 1, 2, 3). Main result of the volume change is summarized in the Table 2. The Only patient who required DEBIRI twice achievied stable disease.

\section{Safety}

No abnormal laboratory data was present 3 days after the procedure whereas slight increase in $\mathrm{WBC}, \mathrm{LDH}$, GOT/GPT and prot $\mathrm{C}$ reactive were observed within the first $48 \mathrm{~h}$ hours (Table 3 ). Mild fever lasting one to three days and procedure related pain were observed in $10 / 12$ $(80 \%)$ patients. Persisting muchorrea and tenesmo were reported by 4 patients (33\%). The length of In Hospital stay is 3 to 7 days after DEBIRI.

The median OS was 12 months (CI 95\%: 5 to 18). (Table 4).

\section{DISCUSSION}

Approximately $20 \%$ of rectal cancer patients presents with unresectable locally advanced or metastatic disease $[10,11]$. Approximately one-half of patients who underwent "curative" resection for localized disease will eventually die of metastatic disease [12]. During that time, patients may present with a variety of disease-related, psychological 
Table 1: Patients characteristics

\begin{tabular}{|c|c|c|c|c|c|}
\hline Patients age (years) & PS ECOG & Comorbidities & $\begin{array}{c}\text { Clinical } \\
\text { Presentation }\end{array}$ & $\begin{array}{c}\text { Follow -up } 6 \\
\text { months } \\
\end{array}$ & Survival (months) \\
\hline 90 & 2 & $\begin{array}{l}\text { COPD } \\
\text { CAD }\end{array}$ & $\begin{array}{l}\mathrm{RB} \\
\mathrm{BO}\end{array}$ & Stable & 10 \\
\hline 71 & 2 & $\begin{array}{c}\text { Child B } \\
\text { CAD with left } \\
\text { ventricular } \\
\text { hypokinesia }\end{array}$ & $\begin{array}{l}\mathrm{RB} \\
\mathrm{BO} \\
\text { Pain }\end{array}$ & Stable disease & 5 \\
\hline 87 & $2 / 3$ & $\begin{array}{l}\text { Essential } \\
\text { hypertension, } \\
\text { Chronic Atrial } \\
\text { Fibrillation, } \\
\text { Asthma }\end{array}$ & $\begin{array}{c}\text { RB } \\
\text { Pain } \\
\text { Tenesmus }\end{array}$ & Stable & 11 \\
\hline 70 & 2 & $\begin{array}{c}\text { COPD } \\
\text { CAD with } \mathrm{CCHF}\end{array}$ & $\begin{array}{c}\text { BO } \\
\text { Pain } \\
\text { Tenesmus } \\
\text { Minimal RB }\end{array}$ & Stable disease & 13 \\
\hline 42 & 2 & None & $\begin{array}{c}\text { RB } \\
\text { Pain } \\
\text { Tenesmus } \\
\end{array}$ & Stable disease & 18 \\
\hline 64 & 2 & $\begin{array}{l}\text { CAD } \\
\text { COPD }\end{array}$ & $\begin{array}{l}\mathrm{RB} \\
\mathrm{BO}\end{array}$ & $\begin{array}{l}\text { Stable disease } \\
\text { after surgery }\end{array}$ & 18 \\
\hline 62 & 2 & $\begin{array}{c}\text { Essential } \\
\text { Hypertension }\end{array}$ & $\begin{array}{l}\mathrm{RB} \\
\mathrm{BO}\end{array}$ & $\begin{array}{c}\text { No recurrence after } \\
\text { surgery } \\
\text { Ongoing } \\
\text { oncological } \\
\text { therapy } \\
\end{array}$ & 15 \\
\hline 80 & 2 & $\begin{array}{l}\text { CAD } \\
\text { COPD }\end{array}$ & $\begin{array}{l}\mathrm{RB} \\
\mathrm{BO}\end{array}$ & $\begin{array}{c}\text { Stable disease after } \\
\text { surgery }\end{array}$ & 6 \\
\hline 73 & 2 & Child A & $\begin{array}{l}\mathrm{RB} \\
\mathrm{BO} \\
\text { Pain } \\
\end{array}$ & $\begin{array}{l}\text { Stable disease } \\
\text { after surgery }\end{array}$ & 16 \\
\hline 64 & 2 & $\begin{array}{l}\text { COPD } \\
\text { Child B }\end{array}$ & $\begin{array}{c}\mathrm{BO} \\
\mathrm{RB} \\
\text { Tenesmus } \\
\end{array}$ & Stable disease & 12 \\
\hline 88 & $2 / 3$ & $\begin{array}{c}\text { Dilatative } \\
\text { Cardiomiopathy } \\
\text { Asthma }\end{array}$ & $\mathrm{RB}$ & Stable disease & 5 \\
\hline 56 & 2 & $\begin{array}{c}\text { Essential } \\
\text { hypertension }\end{array}$ & $\begin{array}{c}\text { RB } \\
\text { Tenesmus } \\
\end{array}$ & Stable disease & 5 \\
\hline
\end{tabular}

$70 \pm 14$

$11 \pm 5$

Legends: $\mathrm{CHT}=$ chemotherapy; $\mathrm{RT}=$ radiotherapy; $\mathrm{RB}=$ rectal bleeding; $\mathrm{BO}=$ bowel obstruction;

Legends: $\mathrm{CHT}=$ chemotherapy; $\mathrm{RT}=$ radiotherapy; $\mathrm{RB}=$ rectal bleeding; $\mathrm{BO}=$ bowel obstruction;

$\mathrm{COPD}=$ Chronic Obstructive Pulmonary Disease; $\mathrm{CAD}=$ Coronary artery disease; $\mathrm{CCHF}=$ chronic congestive heart failure;

and physical symptoms: obstruction, bleeding, perforation, pain, weight loss, and fatigue, all affecting and worsening quality of life [4]. Approximately 30 to $50 \%$ of these patients die with the locally recurrent tumor the only manifestation of the disease, without experiencing systemic synchronous or metachronous metastases [3].
Angiography for treatment of inoperable and symptomatic patient has been described in the past, with only few articles covering a broad spectrum of diseases including colorectal cancer [13-15].

TACE has been widely used in the past, primarily to treat liver metastases mainly from CRC, but, to the best of 


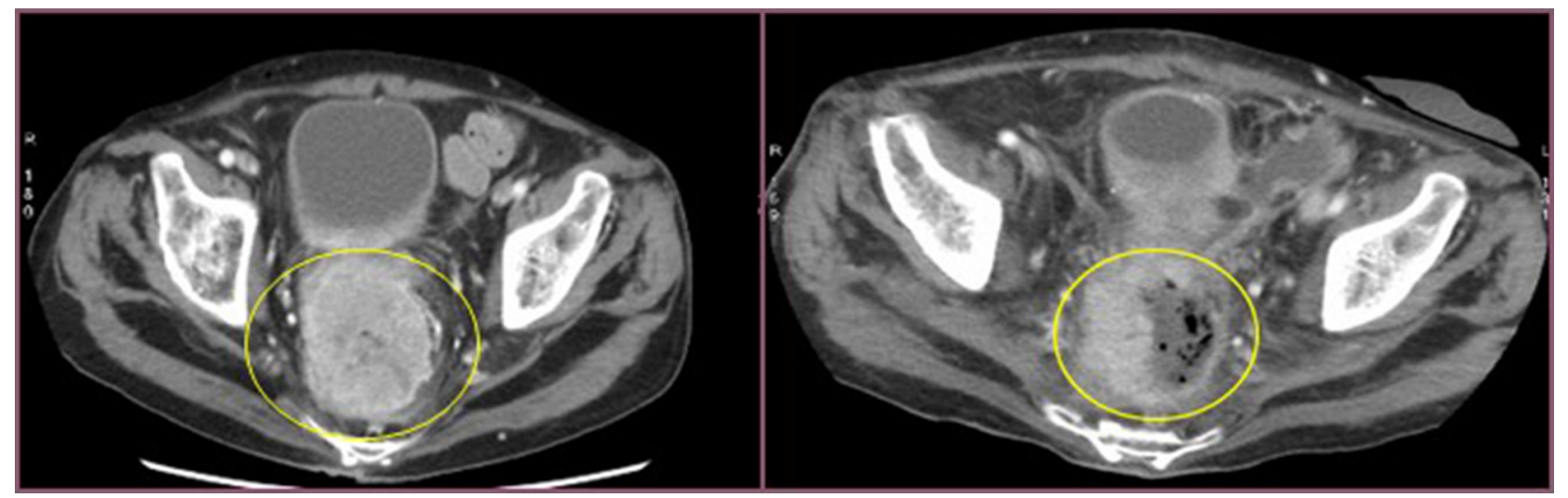

Figure 1: Cross section of contrast enhanced CT scan of the pelvis (venous phase). Left image: into the yellow circle tumor before chemoembolisation. Right image: into the yellow circle the reduction size of the lesion (30 day after treatment).
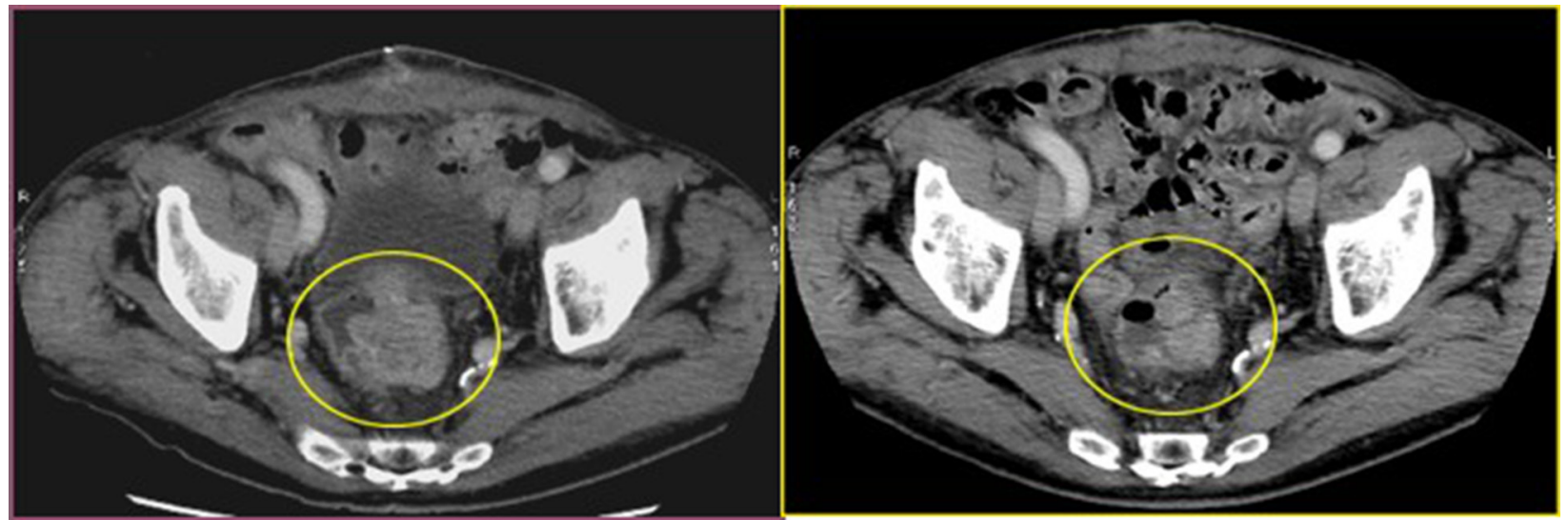

Figure 2: Cross section of contrast enhanced CT scan of the pelvis (venous phase). Left image: into the yellow circle tumor before chemoembolisation; Right image : into the yellow circle the reduction size of the lesion (30 day after treatment).
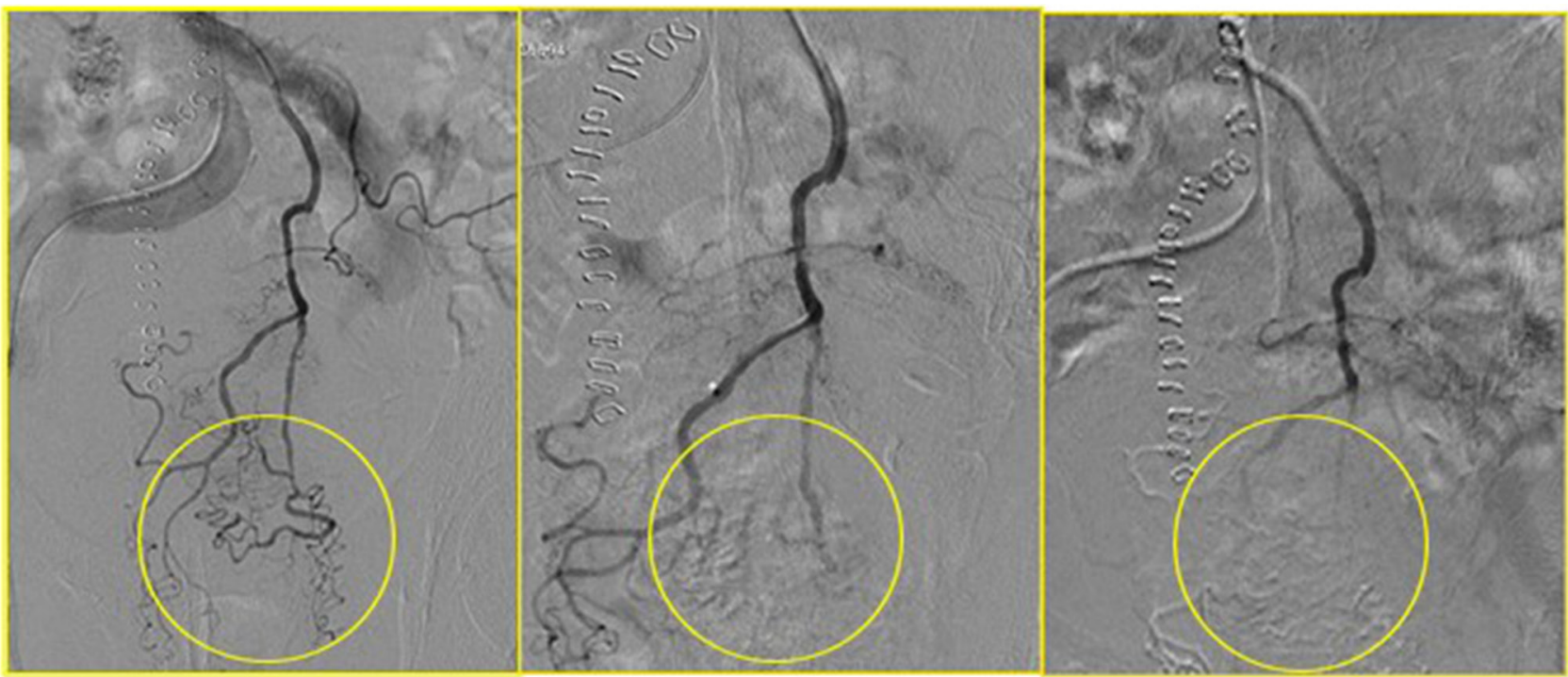

Figure 3: In yellow circle the pregressive disappearing of the tumor vascular bed during the chemoembolisation. 
Table 2: Radiological evaluation of treatment's response assessed by different criteria

\begin{tabular}{|c|c|c|c|c|c|}
\hline \multicolumn{2}{|c|}{ RECIST } & \multicolumn{2}{|c|}{ mCHOI } & \multirow{2}{*}{$\begin{array}{c}\text { MASS } \\
\text { Type of response }\end{array}$} & \multirow{2}{*}{$\begin{array}{c}\begin{array}{c}\text { NEW Volume } \\
\text { Criteria }\end{array} \\
\% \text { of reduction }\end{array}$} \\
\hline$\%$ of reduction & Type of response & $\%$ of reduction & $\begin{array}{c}\text { Type of } \\
\text { response }\end{array}$ & & \\
\hline $37 \%$ & PR & $41 \%$ & PR & FAVORABLE & $75 \%$ \\
\hline $30 \%$ & PR & $24 \%$ & PR & FAVORABLE & $66 \%$ \\
\hline $8 \%$ & SD & $15 \%$ & PR & UNDETERMINED & $12 \%$ \\
\hline $51 \%$ & PR & $9 \%$ & SD & UNDETERMINED & $55 \%$ \\
\hline $0 \%$ & SD & $50 \%$ & PR & FAVORABLE & $63 \%$ \\
\hline $0 \%$ & SD & $53 \%$ & PR & FAVORABLE & $11 \%$ \\
\hline $66 \%$ & PR & $0 \%$ & SD & FAVORABLE & $96 \%$ \\
\hline $18 \%$ & PD & $17 \%$ & PR & UNDETERMINED & $7 \%$ \\
\hline $32 \%$ & PR & $20 \%$ & PR & FAVORABLE & $24 \%$ \\
\hline $18 \%$ & PR & 1 & SD & UNFAVORABLE & $5 \%$ \\
\hline $31 \%$ & PR & 18 & PR & FAVORABLE & 35 \\
\hline $28 \%$ & PR & 20 & PR & FAVORABLE & $28 \%$ \\
\hline
\end{tabular}

Legend: $\mathrm{PR}=$ Partial response; $\mathrm{PD}$ : Progression of the disease; $\mathrm{SD}=$ Stable disease.

Table 3: Patients treatment and adverse event

\begin{tabular}{|c|c|c|c|c|c|}
\hline Patients & Previous Therapy & $\begin{array}{c}\text { Number } \\
\text { of treat }\end{array}$ & $\begin{array}{l}\text { Adverse } \\
\text { Event }\end{array}$ & DC Beads size & Laboratory data \\
\hline 1 & $\begin{array}{c}\text { No Surg } \\
\text { No CHT or RT }\end{array}$ & 1 & Pain Fever & $\begin{array}{l}100-300 \text { and } \\
300-500 \mu \mathrm{m}\end{array}$ & $\begin{array}{c}\text { Increase of: WBC AST/ALT } \\
\text { Prot C }\end{array}$ \\
\hline 2 & $\begin{array}{c}\text { No Surg } \\
\text { No CHT } \\
\text { In progression } \\
\text { after RT }\end{array}$ & 1 & Fever & $\begin{array}{l}100-300 \text { and } \\
300-500 \mu \mathrm{m}\end{array}$ & $\begin{array}{c}\text { Increase of: WBC } \\
\text { LDH }\end{array}$ \\
\hline 3 & $\begin{array}{c}\text { No Surg } \\
\text { Not eligible for CHT and RT }\end{array}$ & 1 & Tenesm & $\begin{array}{l}100-300 \text { and } \\
300-500 \mu \mathrm{m}\end{array}$ & $\begin{array}{c}\text { Increase of: WBC } \\
\text { LDH } \\
\text { AST/ALT }\end{array}$ \\
\hline 4 & $\begin{array}{c}\text { No Surg } \\
\text { Not eligible for CHT and RT }\end{array}$ & 1 & Tenesm & $\begin{array}{l}100-300 \text { and } \\
300-500 \mu \mathrm{m}\end{array}$ & $\begin{array}{c}\text { Increase of: } \\
\text { WBC } \\
\text { Reactive C Protein }\end{array}$ \\
\hline 5 & $\begin{array}{c}\text { Recurrence after Surgery and } \\
\mathrm{CH} / \mathrm{RT}\end{array}$ & 1 & Fever & $\begin{array}{l}100-300 \text { and } \\
300-500 \mu \mathrm{m}\end{array}$ & $\begin{array}{c}\text { Increase of: } \\
\text { WBC } \\
\text { AST/ALT } \\
\text { LDH }\end{array}$ \\
\hline 6 & $\begin{array}{c}\text { Recurrence after Surgery } \\
\text { No CHT and RT }\end{array}$ & 1 & Fever & $\begin{array}{l}100-300 \text { and } \\
300-500 \mu \mathrm{m}\end{array}$ & $\begin{array}{c}\text { Increase of: } \\
\text { WBC } \\
\text { AST/ALT } \\
\text { LDH }\end{array}$ \\
\hline 7 & $\begin{array}{c}\text { No surgery in progression } \\
\text { after CHT and RT }\end{array}$ & 1 & Fever & $\begin{array}{l}100-300 \text { and } \\
300-500 \mu \mathrm{m}\end{array}$ & $\begin{array}{l}\text { Increase of: } \\
\text { WBC } \\
\text { LDH }\end{array}$ \\
\hline
\end{tabular}




\begin{tabular}{|c|c|c|c|c|c|}
\hline 8 & $\begin{array}{l}\text { Recurrence after surgery } \\
\text { No CHT or RT }\end{array}$ & 2 & $\begin{array}{l}\text { Fever } \\
\text { Tenesm }\end{array}$ & $\begin{array}{l}100-300 \text { and } \\
300-500 \mu \mathrm{m}\end{array}$ & $\begin{array}{c}\text { Increase of: } \\
\text { WBC } \\
\text { AST/ALT } \\
\text { Reactive C protein }\end{array}$ \\
\hline 9 & $\begin{array}{c}\text { Recurrence after surgery and } \\
\text { CHT }\end{array}$ & 1 & Fever & $\begin{array}{l}100-300 \text { and } \\
300-500 \mu \mathrm{m}\end{array}$ & $\begin{array}{c}\text { Increase of: } \\
\text { WBC } \\
\text { AST/ALT } \\
\end{array}$ \\
\hline 10 & Recurrence after surgery & 1 & Fever & $\begin{array}{l}100-300 \text { and } \\
300-500 \mu \mathrm{m}\end{array}$ & $\begin{array}{c}\text { Increase of: } \\
\text { WBC } \\
\text { AST/ALT } \\
\end{array}$ \\
\hline 11 & $\begin{array}{c}\text { No surg } \\
\text { No CHT } \\
\text { No RT }\end{array}$ & 1 & Fever & $\begin{array}{l}100-300 \text { and } \\
300-500 \mu \mathrm{m}\end{array}$ & $\begin{array}{c}\text { Increase of: } \\
\text { Reactive C prot } \\
\text { WBC } \\
\text { LDH } \\
\end{array}$ \\
\hline 12 & $\begin{array}{c}\text { In progression after CHT No } \\
\text { RT }\end{array}$ & 1 & $\begin{array}{l}\text { Fever } \\
\text { Tenesm }\end{array}$ & $\begin{array}{l}100-00 \text { and } \\
300-500 \mu \mathrm{m}\end{array}$ & $\begin{array}{l}\text { Increase of: } \\
\text { WBC } \\
\text { LDH } \\
\text { AST/ALT }\end{array}$ \\
\hline
\end{tabular}

Legends: $\mathrm{CHT}=$ chemotherapy; $\mathrm{RT}=$ radiotherapy; $\mathrm{RB}=$ rectal bleeding $; \mathrm{BO}=$ bowel obstruction; $\mathrm{COPD}=\mathrm{Chronic}$ Obstructive Pulmonary Disease; $\mathrm{CAD}=$ Coronary artery disease; $\mathrm{CCHF}=$ chronic congestive heart failure; $\mathrm{WBC}=$ white blood cell; AST = aspartate aminotransferase; ALT = alanine aminotransferase; LDH: lactate dehydrogenase.

Table 4: Patients survival and ESAS score (pain)

\begin{tabular}{|c|c|c|c|}
\hline Patients age (years) & $\begin{array}{c}\text { ESAS score PAIN } \\
\text { Before/after }\end{array}$ & 10 & Survival (months) \\
\hline 90 & $7 / 3$ & 5 & $75 \%$ \\
\hline 71 & $7 / 3$ & 11 & $66 \%$ \\
\hline 87 & $7 / 3$ & 13 & $12 \%$ \\
\hline 70 & $7 / 4$ & 18 & $55 \%$ \\
\hline 42 & $7 / 3$ & 18 & $63 \%$ \\
\hline 64 & $6 / 4$ & 15 & $11 \%$ \\
\hline 62 & $7 / 2$ & 6 & $96 \%$ \\
\hline 80 & $6 / 3$ & 16 & $7 \%$ \\
\hline 73 & $7 / 4$ & 12 & $24 \%$ \\
\hline 64 & $7 / 4$ & 5 & $5 \%$ \\
\hline 88 & $7 / 4$ & 5 & 35 \\
\hline 56 & $7 / 3$ & $11 \pm 5$ & $28 \%$ \\
\hline $70 \pm 14$ & & & $39 \pm 26$ \\
\hline
\end{tabular}

Legend: ESAS: Edmonton Symptom Assessment System.

our knowledge, this is the first report of Debiri for the treatment of locally advanced rectal cancer unsuitable for further local or systemic treatment.

The primary objectives of the study were feasibility, safety and symptoms control of DEBIRI in rectal cancer patients. The procedure was performed without any major serious event occurred. We run an ESA score to assess the benefit of the treatment (Table 4). Clinical benefit was achieved in all the patients.
The secondary endpoint was response rate and Overal survival. One of the challenges we faced had been identifying objective criteria to assess response in hollow organ like the rectum. We adopted the volume criteria which was obtained by combining 3 different assessing tools: MASS, RECIST and mChoi criteria. According to volume criteria virtually any patient had a degree of response and 4 patients (33\%) had a remarkable response which led to radical surgical resection. 
Patients with recurrent rectal cancer and poor performance status are known to have a very grim prognosis with a median overall survival of less than 6 months. Albeit the small group of patients, the OS in the study was 12 months (range 5-18) which represents an outstanding result.

A possible weakness of the study was the difficulty to radiologically assess the patients once on follow up. This was mainly due to patients poor performance status. The patients compliance after the procedure was certainly in line with what we'd expect and many of them did not turn up for their follow up CT scan appointment. Although we follow them up remotely, we can't really make any comment on the progression free survival.

The study has met the primary end point and has gone quite beyond our expectations in term of RR and OS in a poor prognostic group of patients.

This preliminary study has certainly proven that the DEBIRI is safe and could effectively relief cancer symptoms. We have also reported exceptional responses which had been archived with minimal adverse event and led to surgical resection in 4 patients.

Further trials, perhaps in an earlier stage, are warranted to further validate the procedure.

\section{MATERIALS AND METHODS}

We have run a prospective mono-institutional study of TACE-Debiri as an exclusive treatment for locally advanced rectal cancer not suitable for any further treatment option. The study was conducted according to the provisions of the Declaration of Helsinki and The good Clinical Practice Guidelines of the international Conference on harmonization. All patients provided written informed consent form to participate in the study.

We enrolled patients who had had previous histology confirmation of rectal cancer, inoperable or not treatable due to severe comorbidities, and/or pelvic recurrence/ progression after curative treatment, chemotherapy (CHT), radiotherapy (RT) and/or surgery and poor performance status ECOG $(\mathrm{PS} \geq 2)$.

Each patient underwent an abdominal quadriphasic CT scan (64slices General electric CT scanner) in order to obtain a preliminary arterial mapping of the tumour lesion and chest $\mathrm{CT}$ scan to complete the staging.

A diagnostic angiography of superior and inferior mesenteric arteries (SMA and IMA) was performed to define tumour vascularization and feeding arteries, and identify the best target vessels for the treatment and under local anesthesia a $5 \mathrm{~F}$ sheath was inserted using a femoral access . Only in a single case, a selective catheterization of ipogastric artery was also performed.

\section{Debiri procedure}

Using a microcatether, under ultrasound fluoroscopic guidance, a solution of 1 up to $2 \mathrm{ml}$ of irinotecan drugeluting beads (DC-Bead, Biocompatible, UK Ltd) and non-ionic contrast medium was injected into the artery feeding the lesions.

Eleven patients required the procedure only once and 1 patient was treated with Debiri twice with a 30 days gap.

In all cases 100-300 micron irinotecan-charged dc beads were used and in selective cases the procedure was completed injecting 300-500 micron drug- eluting beads.

All the patients had an unenhanced CT study at 24-48 hours after the procedure to exclude periprocedural complications as bleeding, ischemic necrosis or perforation.

A quadriphasic CT study with the same CT scanner was performed one month later as restaging of the treated lesion.The response was read by the treating physician and an independent investigator.

\section{Imaging and tumour response}

Due to the lack of specific criteria to assess solid tumor in hollow viscous we moved to a different diagnostic criteria adopting the 3D volume reduction, size attenuation, morphology and structural change on venous phase CT (MASS) [16], contrast enhanced during mod Choi [17] and RECIST criteria [18].

Using standard criteria, RECIST, was not felt to be accurate enough as this could have had underestimated the overall benefit of the treatment.

Since RECIST was published in 2000, many investigators have confirmed in prospective analyses the validity of substituting unidimensional for bi-dimensional based criteria (With rare exceptions (e.g. mesothelioma)). This makes very difficult to quantify the response of solid tumour in allow viscous. We have overcome this limitation by adopting the concept of steady mass through 3 different worldwide, accepted criteria for solid tumor evaluation: MASS that assesses the change in the attenuation patterns of contrast enhancement on contrast-enhanced CT (CECT); RECIST that is the traditional method of evaluating therapy response based on measurements of long-axis tumor size on axial CT according to the Response Evaluation Criteria in Solid Tumors and mChoi criteria that was initially conceived to assess tumor response in patients with advanced gastrointestinal stromal tumors who received treatment with imatinib, and the criteria were evaluated by computed tomography (CT) scans and validated based on progression-free survival.

Grading of the adverse events was determined using CTCAE version 4. Primary endpoints of the study 
were feasibility, safety and symptoms control Secondary endpoints were response rate (RR), defined as volume reduction of target lesion and overall survival (OS), defined as time from the last TACE-DEBIRI treatment to death.

\section{CONFLICTS OF INTEREST}

The Authors declare no conflicts of interest.

\section{FUNDING} of Health.

This study was supported by the National Institute

\section{REFERENCES}

1. Glimelius B, Tiret E, Cervantes A, Arnold D. Rectal cancer: ESMO Clinical Practice Guidelines for diagnosis, treatment and follow-up. Ann Oncol. 2013; 24:vi81-vi88. doi: 10.1093/annonc/mdt240.

2. Hagar FA, Boushey RP. Colorectal cancer epidemiology: incidence, mortality, survival, and risk factors. Clin Colon Rectal Surg. 2009; 22:191-197. doi:10.1055/s-0029-1242458.

3. Pacelli F, Tortorelli AP, Rosa F, Bossola M, Sanchez AM, Papa V, Valentini V, Doglietto GB. Locally Recurrent Rectal Cancer: Prognostic Factors and Long-Term Outcomes of Multimodal Therapy. Ann Surg Oncol. 2010; 17:152-162. doi: 10.1245/s10434-009-0737-5.

4. Wasserberg N, Kaufman HS. Palliation of colorectal cancer. Surg Oncol. 2007; 16:299-310.

5. Lewis AL, Holden RR. DC Bead embolic drug-eluting bead: clinical application in the locoregional treatment of tumours. Expert Opin. Drug Deliv. 2011; 8:153-169. doi: $10.1517 / 17425247.2011 .545388$.

6. Masi G, Allegrini G, Cupini S, Marcucci L, Cerri E, Brunetti I, Fontana E, Ricci S, Andreuccetti M, Falcone A. A Phase I and Pharmacokinetic Study of Irinotecan Given as a 7-Day Continuous Infusion in Metastatic Colorectal Cancer Patients Pretreated with 5-Fluorouracil or Raltitrexed. Clin Cancer Res. 2004; 10:1657-1663.

7. Huppert PE. Chemoembolization using irinotenca eluting Beads. In:CIRSE 2010:presentation 2202,3:Valencia:2010.

8. Richardson LA, Jones GW. A review of the reliability and validity of the Edmonton Symptom Assessment System. Curr Oncol. 2009; 16:53-64.

9. Uwer L, Rotonda C, Guillemin F, Miny J, Kaminsky MC, Mercier M, Tournier-Rangeard L, Leonard I, Montcuquet P, Rauch P, Conroy T. Responsiveness of EORTC QLQ-C30, QLQ-CR38 and FACT-C quality of life questionnaires in patients with colorectal cancer. Health Qual Life Outcomes. 2011; 9:70. Doi:10.1186/1477-7525-9-70.
10. Rosen SA, Buell JF, Yoshida A, Kazsuba S, Hurst R, Michelassi F, Millis JM, Posner MC. Initial presentation with stage IV colorectal cancer: how aggressive should we be?. Arch Surg. 2000; 135:530-4.

11. Greenlee RT, Murray T, Bolden S, Wingo PA. Cancer statistics 2000. CA Cancer J Clin. 2000; 50:7-33.

12. Simmonds PC. Palliative chemotherapy for advanced colorectal cancer: systematic review and meta-analysis. Colorectal Cancer Collaborative Group. BMJ. 2000; 321:531-5.

13. Gu J, Ma ZL, Li Y, Li M, GW. Angiography for diagnosis and treatment of colorectal cancer. World J Gastroenterol. 2003; 9:288-290.

14. Kato T, Sato K, Sasaki R, Kakinuma H, Moriyama M. Targeted cancer chemotherapy with arterial microcapsule chemoembolization: review of 1013 patients. Cancer Chemother Pharmacol. 1996. 37:289-296.

15. Xu J, Zhong Y, Weixin N, Xinyu Q, Yanhan L, Li R, Jianhua W, Zhiping Y, Jiemin C.. Preoperative Hepatic and Regional Arterial Chemotherapy in the Prevention of Liver Metastasis After Colorectal Cancer Surgery. Ann Surg. 2007; 245:583-90.

16. Smith AD, Shah SN, Rini BI, Lieber ML, Remer EM. Morphology, Attenuation, Size, and Structure (MASS) Criteria: Assessing Response and Predicting Clinical Outcome in Metastatic Renal Cell Carcinoma on Antiangiogenic Targeted Therapy. AJR 2010.194 :14701478; doi: 10.2214/AJR.09.3456

17. Choi H, Charnsangavej C, Faria SC, Macapinlac HA, Burgess MA, Patel SR, Chen LL, Podoloff DA, Benjamin RS. Correlation of Computed Tomography and Positron Emission Tomography in Patients With Metastatic Gastrointestinal Stromal Tumor Treated at a Single Institution With Imatinib Mesylate: Proposal of New Computed Tomography Response Criteria. J Clin Oncol. 2007. 25:1753-1759.

18. Eisenhauer EA, Therasse P, Bogaerts J, Schwartz LH, Sargent D, Ford R, Dancey J, Arbuck S, Gwyther S, Mooney M, Rubinstein L, Shankar L, Dodd L, et al. New response evaluation criteria in solid tumours: Revised RECIST guideline (version 1.1). Eur J Cancer. 2009; 45:228-247. doi: 10.1016/j.ejca.2008.10.026. 